\title{
Lithological Study and Mapping of Barind Tract Using Borehole Log Data with GIS: In the Context of Tanore Upazila
}

\author{
Md. Marufur Rahman, A. Q. M. Mahbub \\ Geography and Environment, University of Dhaka, Dhaka, Bangladesh \\ Email: marufurahman@yahoo.com
}

Received June 6, 2012; revised July 4, 2012; accepted August 1, 2012

\begin{abstract}
In this paper the lithological study and mapping of Barind Tract is done by using irrigation boreholes log data in the context of an upazila under Barind Tract in northwest Bangladesh. Northwestern part of Bangladesh is severely drought prone area with lowest yearly rainfall in the country. Before groundwater irrigation only one crop was cultivated in this area in rainy season. After spreading of groundwater irrigation agriculture is flourished here, but groundwater level is severely going down, which is making this area risky for several adverse effect like land subsidence, biodiversity loss etc. Lithology is one of the important factors that affect the recharging of groundwater aquifer of any area. This research mainly based on secondary data. Irrigation boreholes log data are collected from Barind Multipurpose Development Authority (BMDA), a local authority under the Ministry of Agriculture of Bangladesh government provide irrigation in Barind Tract. A GPS survey is conducted to locate the boreholes in the study area. From the study highest thickness of clay layer found $90 \mathrm{ft}$ and lowest $20 \mathrm{ft}$, and thickness gradually increase from eastern to western side. Aquifer is located between 20 - $90 \mathrm{ft}$ depth from the surface and direction of aquifer is western to eastern side. Agriculture of study area is totally dependent on groundwater irrigation. Thick layer of clay impede recharging of groundwater table. Due to thick layer of sticky and plastic clay land subsidence risk is low, but it act as aquitard which impede groundwater recharging and increase surface runoff.
\end{abstract}

Keywords: Lithology; Barind Tract; Borehole Log; Tanore

\section{Introduction}

Barind Tract is located mostly in the greater districts of Rajshahi, Bogra and Dinajpur with gross area of 7727 sq $\mathrm{km}$ [1]. Geographically the unit lies between latitudes $24^{\circ} 20^{\prime} \mathrm{N}$ and $25^{\circ} 35^{\prime} \mathrm{N}$ and longitudes $88^{\circ} 20^{\prime} \mathrm{E}$ and $89^{\circ} 30^{\prime} \mathrm{E}$. The Barind Tract is floored by the Pleistocene sediment known as Madhupur Clay. The Madhupur Clay is reddish brown in colour, oxidized, sticky and rather compact [2]. Groundwater in Bangladesh occurs at a very shallow depth. Recent river borne sediments form aquifer in the Floodplains. Pleistocene Dupi Tila sands act as aquifer in Barind and Madhupur Tracts and Pliocene Tipam sands serve as the aquifer in hilly area of Bangladesh [3]. Barind Tract is an uplifted block occurs as horst along pre-existing line of crustal weakness. Clay thickness varies from $4 \mathrm{~m}$ in the southwest to over $35 \mathrm{~m}$ in northwest [4]. The permeability of the clay is very low and it is termed as aquitard. With tropical humid monsoon climate in summer, maximum temperature is well $35^{\circ} \mathrm{C}$ and minimum temperature is below $10^{\circ} \mathrm{C}$. Almost $80 \%$ rainfall occur in rainy season in the month of June to
October [5]. Mean annual rainfall is $1250 \mathrm{~mm}$ in the west increasing to almost $2000 \mathrm{~mm}$ in the northwest [6]. Elevation of the area varies from $9 \mathrm{~m}$ to $47 \mathrm{~m}$ PWD (Public Works Datum) [5]. PWD was originally set to the mean sea level (msl) with a vertical error of $\pm 0.45 \mathrm{~m}$ during the Great Trigonometric Survey in the Indian Subcontinent throughout the nineteenth century [7]. Rice dominate the cropping pattern of Barind soil, which suffer from drought in dry season. Only one crop (Aman paddy) in wet season was cultivated in Barind [8]. With the rapid expansion of groundwater irrigation after 1980s, High Yielding Variety (HYV) paddies are introduced in this area. Now Barind Tract produces three crops in one agricultural season with the blessing of groundwater irrigation.

\section{Study Area}

Tanore Upazila is located in northwestern part of Bangladesh and is an upazila under the District of Rajshahi of Rajshahi Division (see Figure 1). The geographical location of the study area is located in between $24^{\circ} 29^{\prime} \mathrm{N}$ and 

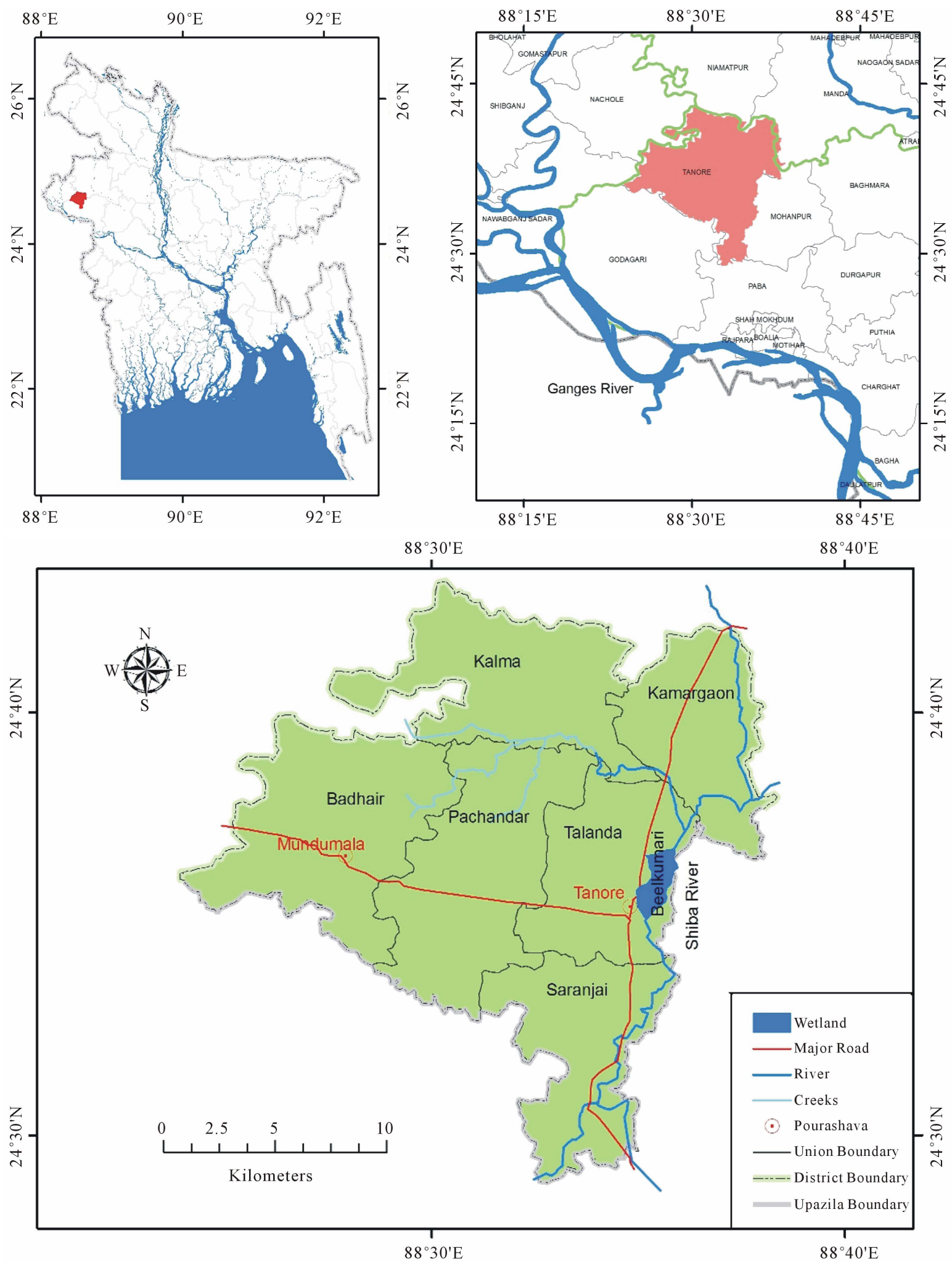

Figure 1. Location map of study area.

$24^{\circ} 43^{\prime} \mathrm{N}$ latitudes and between $88^{\circ} 24^{\prime} \mathrm{E}$ and $88^{\circ} 38^{\prime} \mathrm{E}$ longitudes. Study area has diverse elevation from mean sea level; its elevation increase from eastern side to western side (see Figure 2). The only river Shiba is flowing in eastern most part of the study area and wetland Beelkumari is also located in eastern part. The river 


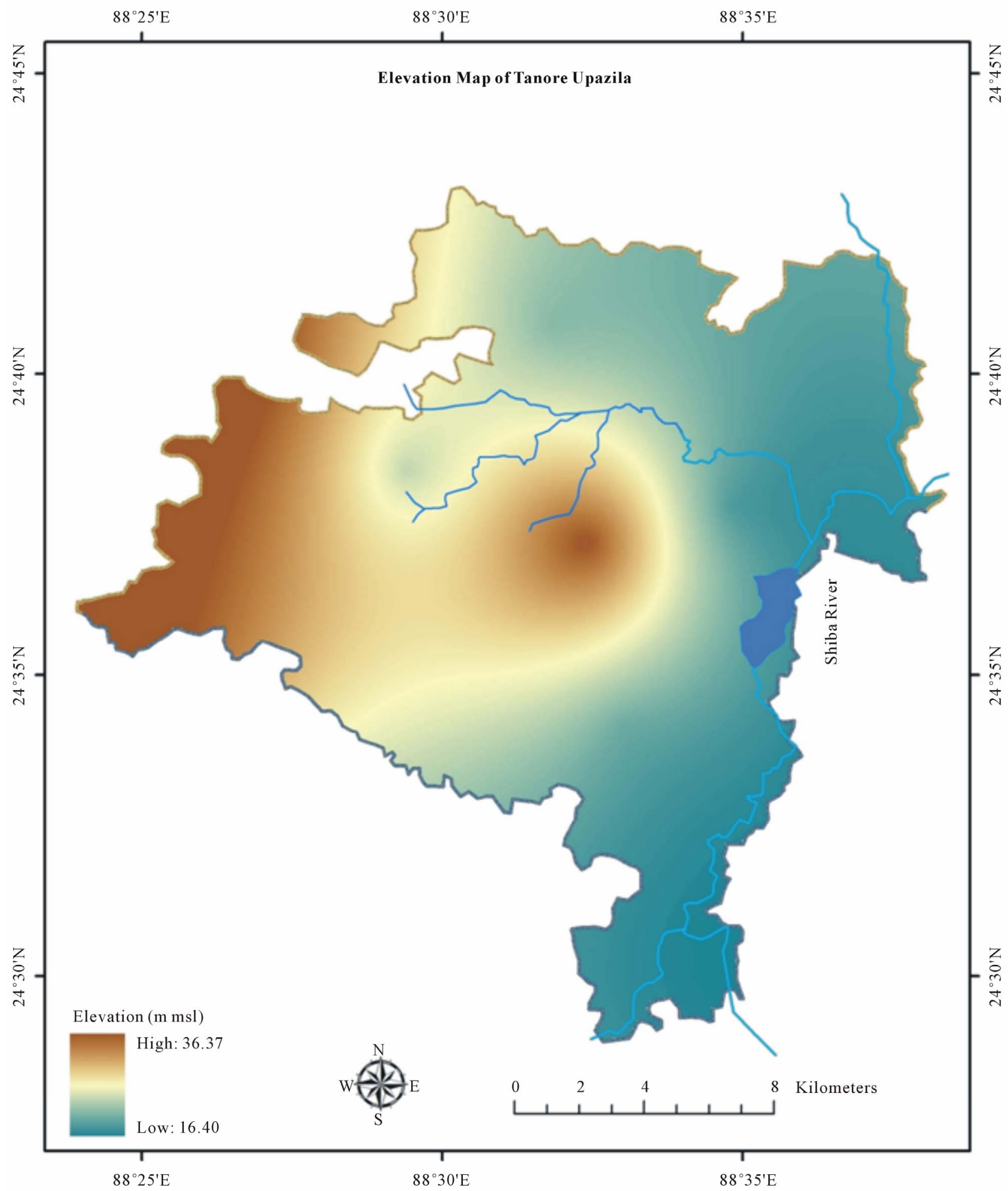

Figure 2. Elevation map of study area from mean sea level (msl).

Shiba originate from the wetland Manda Beel of Manda Upazila under Naogaon District and flowing across the wetland Beelkumari and this river is also fed by numerous creeks originated from the western side of High
Barind Tract. The river and beel almost dried in the winter season and used for boro paddy cultivation by using groundwater from deep tube wells. Physiographically study area includes Barind Tract (81.8\%) Old Gangetic 
Floodplain (3\%), Tista Floodplain (4.8\%) and others (10.4\%) including wetlands, river, homesteads etc. [9]. Soil textural classes of the study area are Clay loam $46 \%$, Loam $35 \%$, Clay $8 \%$ and miscellaneous $11 \%$ (homesteads, wetlands etc) [10].

\section{Data Collection and Methodology}

In this paper irrigation boreholes log data are used to study lithology of the study area collected from Barind Multipurpose Development Authority (BMDA) which is the sole organization for providing irrigation facilities in Barind Tract. Elevation map of study area is generated from 14 Public Works Datum (PWD) located in and around the study area which collected from BWDB (Bangladesh Water Development Board). Analysis of borehole $\log$ data is done by LogPlot 7, software of RockWare and for mapping, ArcGIS is used. To locate the position of boreholes, GPS is used. $\mathrm{X}$ and $\mathrm{Y}$ location is collected by GPS survey of boreholes and after locating borehole, the log data of the borehole are used in mapping. In clay thickness mapping, thickness of the clay is used as $\mathrm{Z}$ value where $\mathrm{X}$ and $\mathrm{Y}$ value is collected by GPS survey (see Figure 3). The whole area having clay layer over the aquifer which varies from place to place, this variation is depicted by clay thickness map. Aquifer is spread beneath all parts of the study area. In the mapping of the depth of aquifer $\mathrm{X}$ and $\mathrm{Y}$ value is used from the GPS survey and thickness of the clay layer of borehole logs used as $\mathrm{Z}$ value which also is the depth of the aquifer from the surface because in Barind Tract Dupi Tila sands aquifer found just beneath the thick clay layer. After input of data it is converted into 3D feature in raster surface and then interpolation is done by kriging method.

\section{Result and Discussion}

Lithological setting of study area vary from eastern to western side with increasing elevation from mean sea level. Western side includes in High Barind Tract whereas; a small portion of the study area in eastern side is under Old Gangetic Floodplain and Tista Floodplain.

Lowest thickness of clay layer was found in the eastern side of the study area near the water body Beelkumari (see Figure 4). The borehole was drilled in 1989 by Bangladesh Agricultural Development Corporation (BADC) under the project of Barind Integrated Area Development Project (BIADP). Available log data from this borehole was about $185 \mathrm{ft}$ from the ground surface (see Figure 5). Thickness of clay layer was $20 \mathrm{ft}$. Fine sand with clay found from $20 \mathrm{ft}$ to $30 \mathrm{ft}$ below the surface. Sand aquifer found $30 \mathrm{ft}$ below the ground with appearance of reddish medium sand. Sand found from 80

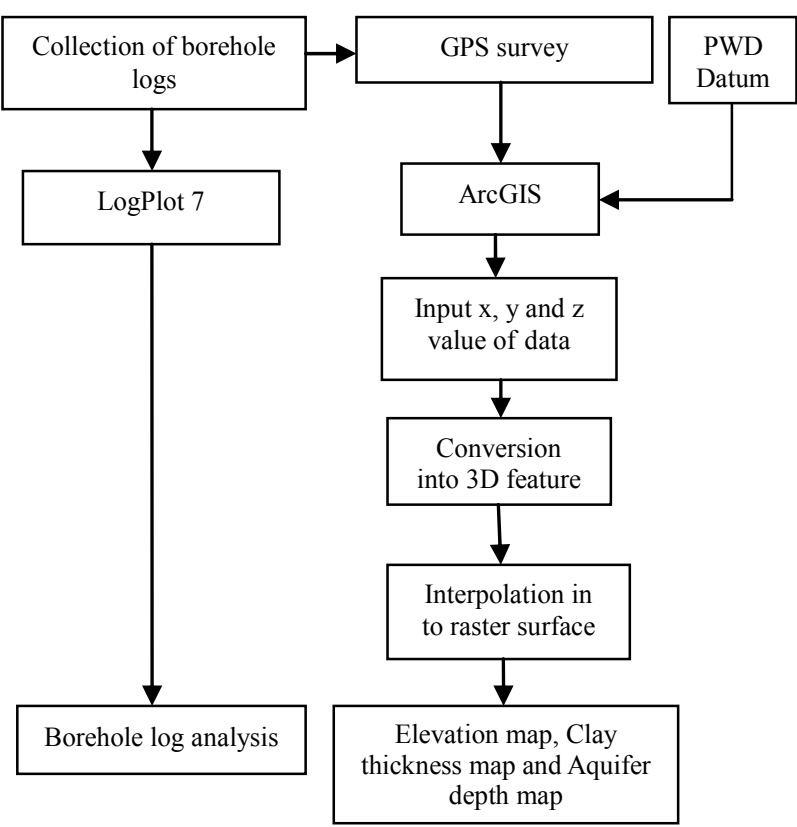

Figure 3. Methodology of the study.

- $90 \mathrm{ft}$. Coarse sand appears from 90 - $180 \mathrm{ft}$ and after $180 \mathrm{ft}$ fine sand found.

From the borehole logs data highest thickness of clay layer is found in western most side of study area in Badhair Union of Tanore Upazila (see Figure 4). The borehole of Jhenakhoir Mouza is drilled by BMDA in 2005. Lithological data of $150 \mathrm{ft}$ is available from the boring of the borehole (see Figure 6). Thickness of the clay layer is highest in this borehole among the all in this study. Clay thickness was about $90 \mathrm{ft}$ and below the depth from the ground sand aquifer found with appearance of brown colored medium sand. After drilling of $135 \mathrm{ft}$ from the ground clay and silt with stone appeared in the area.

About fourteen irrigation boreholes log data (see Figure 7) are used to produce clay thickness map and aquifer depth map of the study area. Thickness of clay increase from eastern to western side and it range from 20 $90 \mathrm{ft}$ in the study area (Figure 8) and Dupi Tila sands aquifer found beneath the clay layer and it also vary from $20 \mathrm{ft}$ to $90 \mathrm{ft}$ of depth from the surface in the study area (Figure 9).

\section{Limitations}

Clay thickness and aquifer depth mapping have done using only fourteen (Figure 7) boreholes log data. Number of borehole log was limited due to unavailability of data and problem of locating the borehole in the study area. During study more than fifty GPS positions of borehole were located but exact log data were available only for fourteen of them. 


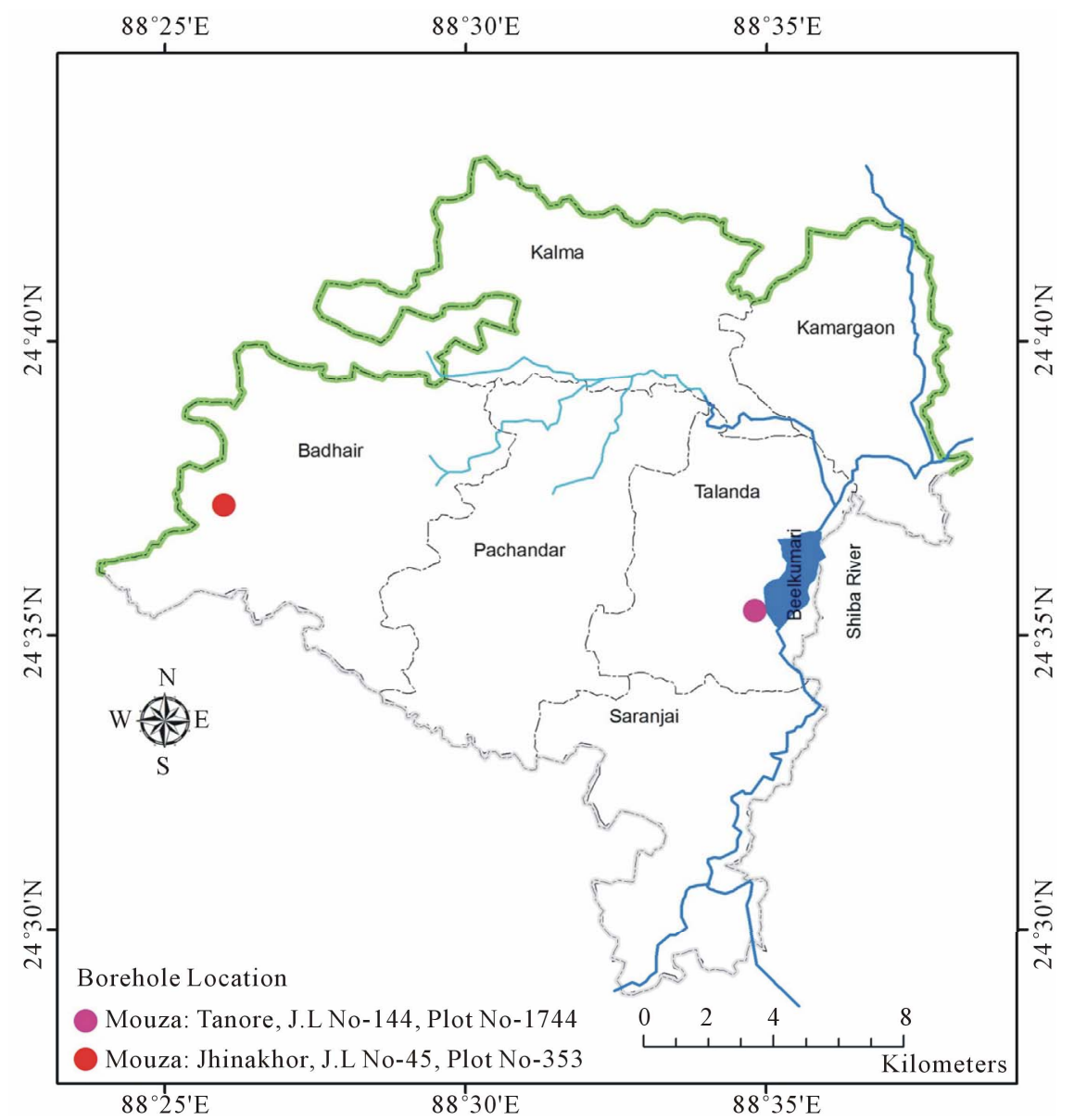

Figure 4. Location of boreholes with highest and lowest clay thickness in study area.

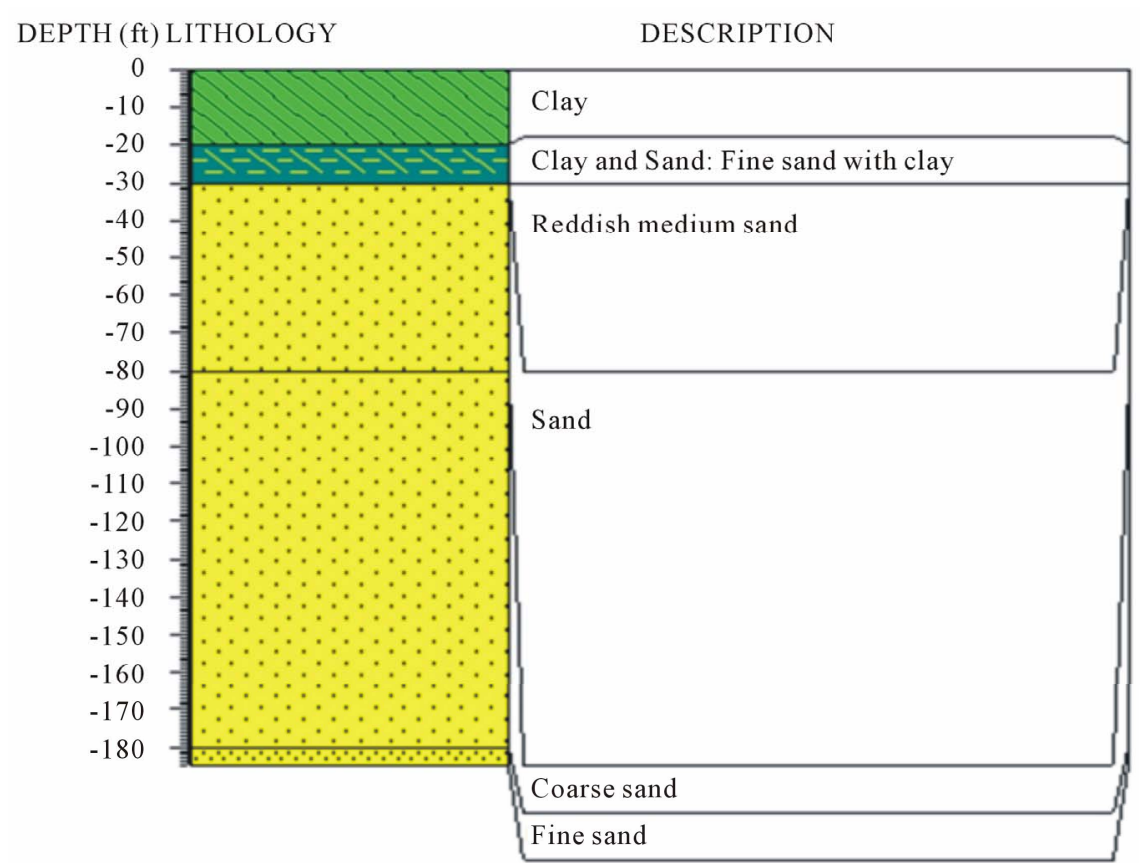

Data source: BMDA (Mouza: Tanore, J.L. No-144, Plot No-1744)

Figure 5. Lowest clay thickness found in study area. 


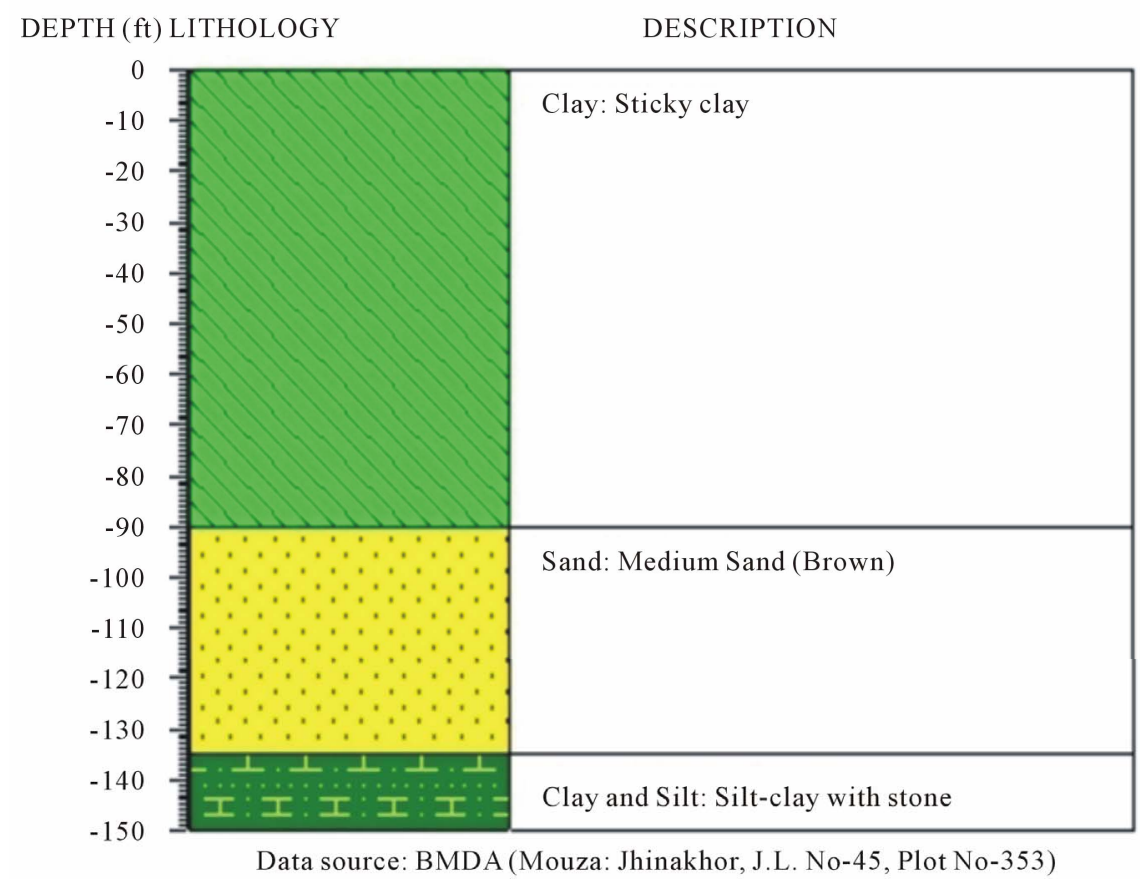

Figure 6. Highest clay thickness found in study area.

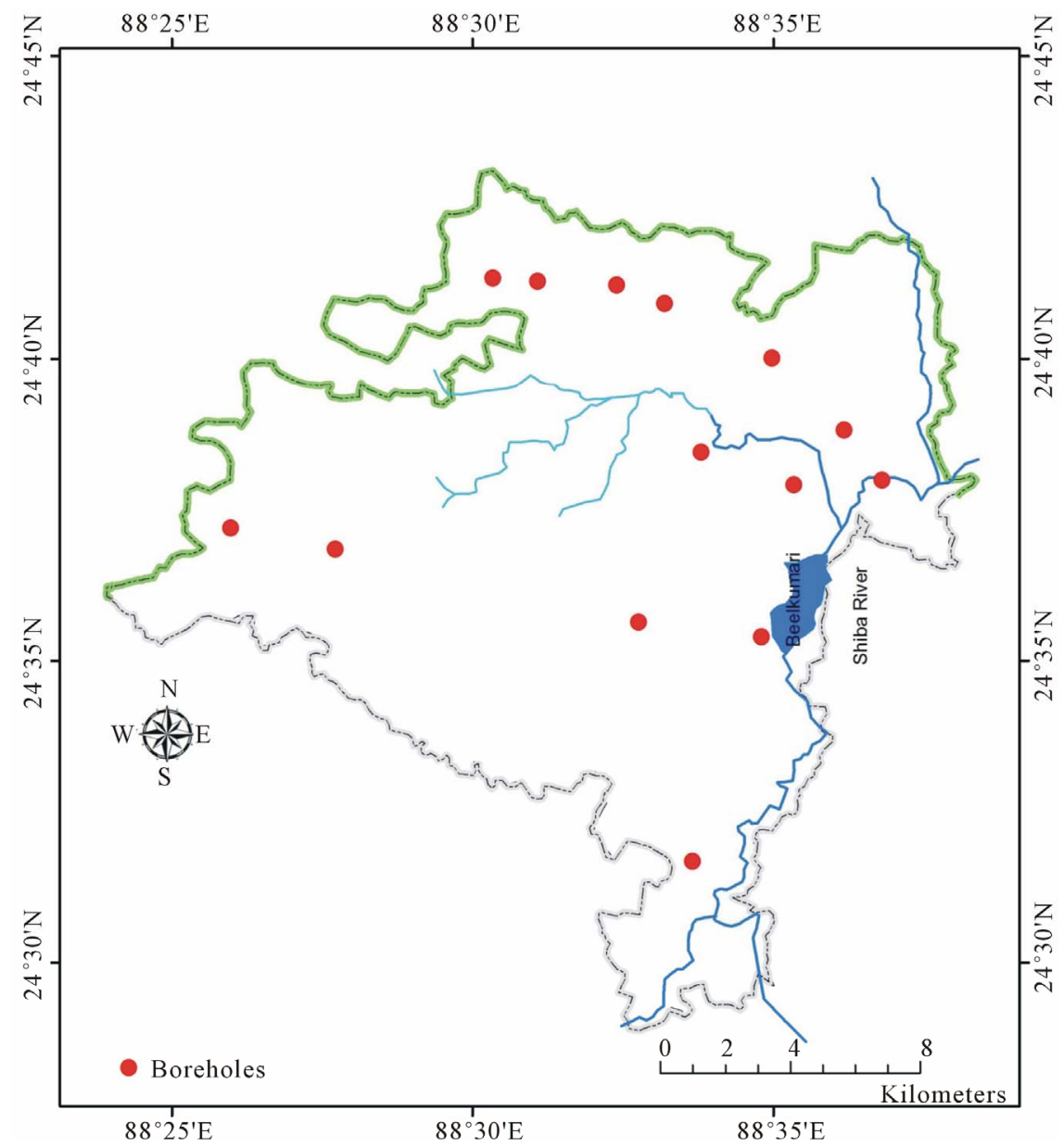

Figure 7. Logs data from boreholes used in clay thickness and aquifer depth mapping. 


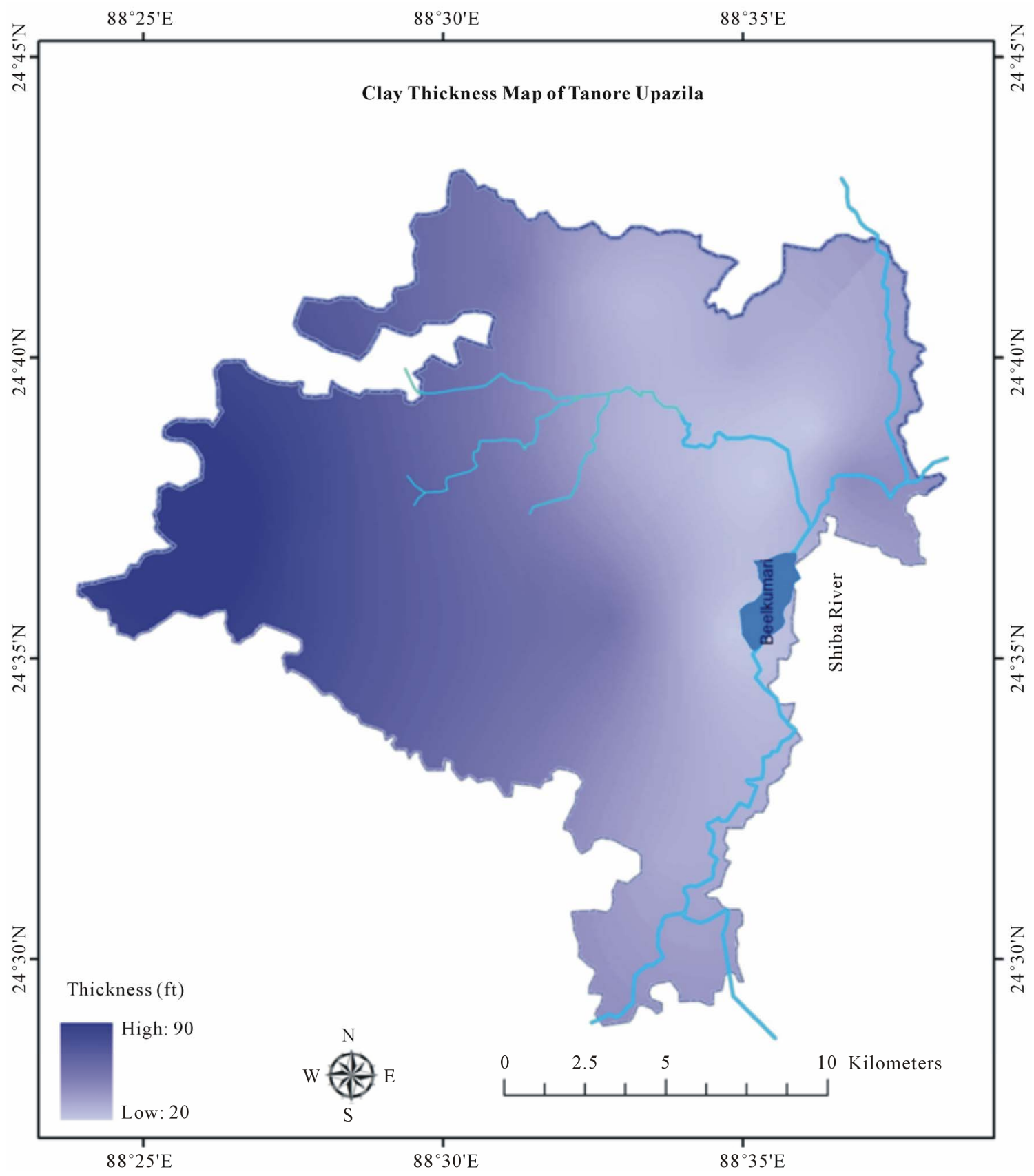

Figure 8. Clay thickness map (ft from the ground surface) of study area.

\section{Conclusion}

From the study, it is found that the thickness of clay vary $20 \mathrm{ft}-90 \mathrm{ft}$ from the eastern to western side of the study area. Dupi Tila sands aquifer found from $20 \mathrm{ft}$ to $90 \mathrm{ft}$ below the surface ground. Lowest amount of rainfall occur in the northwest part of Bangladesh, moreover this area is affected by severe drought in dry season. High thickness of clay acts as aquitard in Barind which impede groundwater recharging and increase runoff during rainy season. Availability of surface water source is also com- paratively limited which provide another source of groundwater recharging. Above all, huge number of deep tube wells are installed to withdraw groundwater for flourishing the agriculture of the area. Due to high thickness of clay layer risk of land subsidence cause by groundwater depletion is low, but sticky nature of clay impede the recharging process of groundwater, as a result excessive groundwater irrigation will deplete the groundwater level which severely impact on surface water bodies and biodiversity of the study area. This study shows that GIS can be effectively used in mapping of 


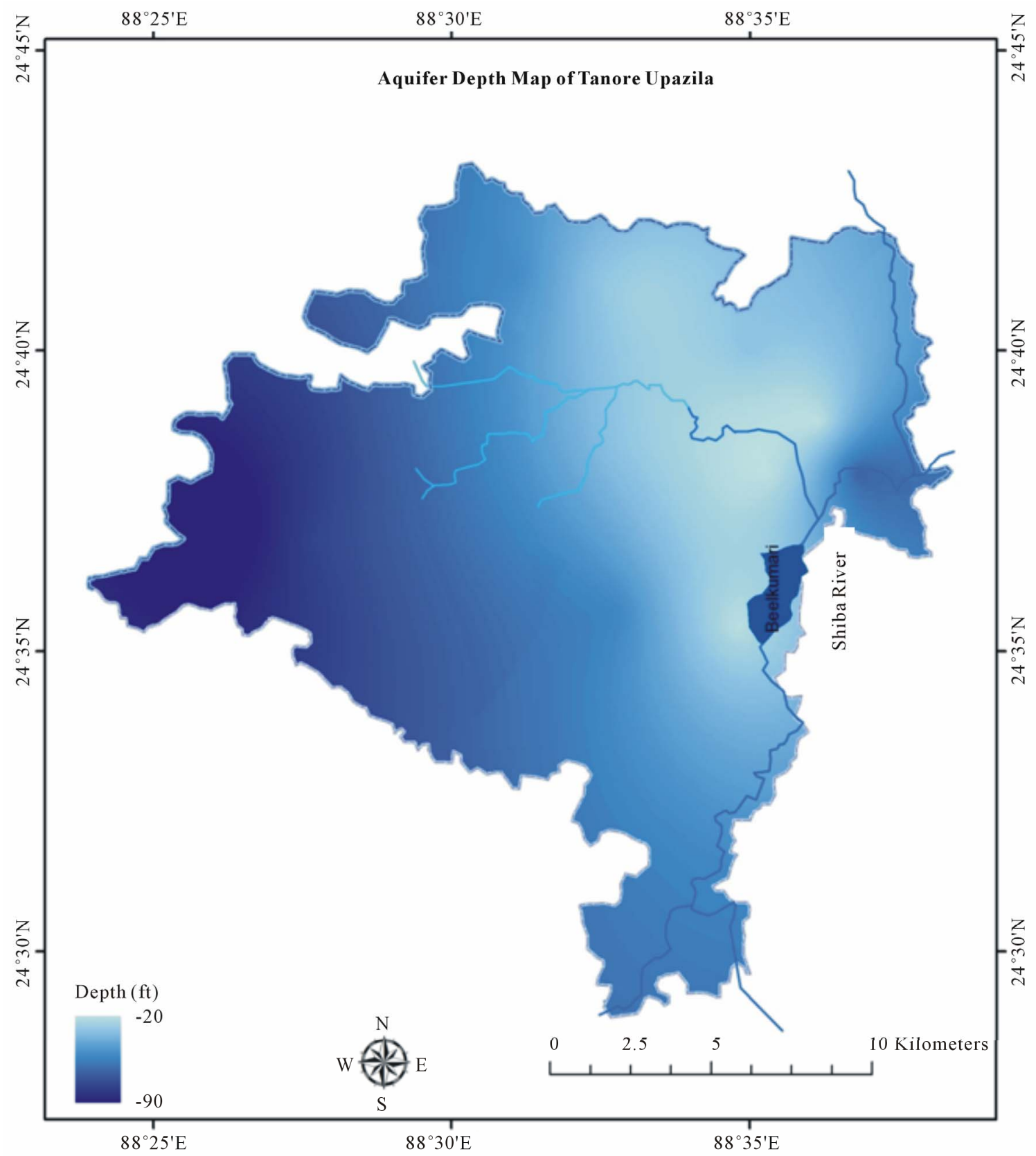

Figure 9. Aquifer depth (ft below the surface) map of study area.

lithological structure of any area. With sufficient accurate data it can produce good quality map which can be useful in decision making and other development works in any area.

\section{Acknowledgements}

The authors would like to acknowledge Dr. Kazi Matin U. Ahmed, Department of Geology of University of Dhaka, Barind Multipurpose Development Authority (BMDA) and Agromet Division of Bangladesh Meteorological Department (BMD) for their financial and other supports.

\section{REFERENCES}

[1] H. Brammer, "Agricultural Development Possibilities in Bangladesh," University Press Limited, Dhaka, 1997, p. 126.

[2] K. M. Ahmed, "Barind Tract," In: S. Islam, Ed., Banglapedia: National Encyclopedia of Bangladesh, Asiatic Society of Bangladesh, Dhaka, 2006.

http://www.banglapedia.org/httpdocs/HT/B_0309.HTM

[3] K. M. Ahmed and M. A. Hossain, "Groundwater," In: S. 
Islam, Ed., Banglapedia: National Encyclopedia of Bangladesh, Asiatic Society of Bangladesh, Dhaka, 2006. http://www.banglapedia.org/httpdocs/HT/G_0209.HTM

[4] BMDA (Barind Multipurpose Development Authority), "Ground Water Model Study for Deep Tubewell Installation Project in Barind Area," Vol. II, 2006, Annex-B, Appendix-A, p. 3.

[5] BMDA (Barind Multipurpose Development Authority), "Ground Water Model Study for Deep Tubewell Installation Project in Barind Area," Vol. I, 2006, pp. 1-2.

[6] K. B. S. Rasheed, "Bangladesh: Resource and Environmental Profile," A H Development Publishing House, Dhaka, 2008, p. 12.

[7] M. Shamsudduha, R. G. Taylor, K. M. Ahmed and A. Zahid, "The Impact of Intensive Groundwater Abstraction on Recharge to a Shallow Regional Aquifer System: Evidence from Bangladesh," Hydrogeology Journal, Vol. 19, No. 4, 2011, pp. 901-916. doi:10.1007/s10040-011-0723-4

[8] IBRD (International Bank for Reconstruction and Development), "IBRD-IDA Tube Well Project," East Pakistan Agricultural Development Corporation, Dhaka, Vol. PA49a, 1970, p. 5.

[9] SRDI (Soil Resource Development Institute), "Upazila Land and Soil Resource Utilization Guide: Tanore, Rajshahi," SRDI, Dhaka, 2000, p. 10.

[10] SRDI (Soil Resource Development Institute), "Land and Soil Statistical Appraisal Book of Bangladesh," SRDI, Dhaka, 2010, p. 155. 